\title{
Research on Heating Clay by Low Carbon Catalytic Combustion Furnace of Natural Gas
}

\author{
Kai Fang, Fan He, Shihong Zhang \\ Beijing Key Lab. of Heating, Gas Supply, Ventilating and Air Conditioning Engineering, Beijing University of Civil \\ Engineering and Arch., Beijing, China \\ Email: shihongzhang@bucea.edu.cn
}

Received October 2014

\begin{abstract}
This article did a research about exhaust gas constituent inside the catalytic combustion furnace with Pd-based honeycomb monoliths of lean natural gas-air mixtures and discussed the feature of the exhaust gas. In addition, the near-zero pollutant emissions of catalytic combustion burner was proved by a test report provided by NIM. From a low-carbon prospective, the application prospect of catalytic combustion furnace was discussed
\end{abstract}

\section{Keywords}

\section{Catalytic Combustion, Low-Carbon, Exhaust Gas Pollutant Emissions}

\section{Introduction}

Energy and environment are two major topics in today's world. At the end of 2006 to the beginning of 2007, the phenomenon that the average temperature has increased universally result of serious reaction, and greenhouse effect that cause global warming became an important problem that people have to face [1]. Many studies focus on new energies, such as nuclear, wind, marine stream and solar energy to find path to low carbon. However, nuclear and many renewable technologies cannot be set in large scale in the short term, because of their uncertainties. In addition, people came into the industrial revolution age at the same with the growing of the content of greenhouse gas, thus can declare the effect of anthropogenic activities to the global climate variation [2]. Research Introduction of Solar Energy in the USA proposed that we should use liquid fuel made from crops, nuclear energy, wind energy, water energy, tidal energy, and many other energy wide-spread, so that we can decrease the dependence on petroleum and fossil fuel [3].

Catalytic combustion, as a new way of burning, nearly $100 \%$ of the fuel conversion can be realized. Compared with flame combustion, catalytic combustion of combustion temperature is low, and can achieve near-zero emissions. This is now the only way can achieve nearly zero emissions of burning [4]. Furthermore, when natural gas burning in average way, it can reach $1800 \mathrm{~K}$ usually, but when it reach $1500 \mathrm{~K}$ the rate of producing of NOx will increase seriously with temperature rising [5]. At present, the main research contents for methane catalytic combustion are: catalytic combustion reaction mechanism, characteristics, application and preparation of the catalyst [6]-[8]. Catalytic combustion is recognized to be a kind of high combustion efficiency. Therefore, the way of catalytic combustion can make natural gas burning almost totally. Through catalytic combustion, the 
disadvantages of flaming can be avoided, and the advantage of catalytic combustion is that catalytic combustion can produce less pollution [9].

\section{Low-Temperature Field inside the Furnace of Catalytic Burner}

\section{Experimental Set-Up}

Figure 1 presents the conventional diagram about the equipment. The core of the system is the catalytic combustion furnace, whose size is $100 \mathrm{~cm}$ long, $180 \mathrm{~cm}$ high and $880 \mathrm{~cm}$ wide. From conventional diagram we can comprehend that there are three catalytic burners which embed in the same side of the catalytic combustion furnace, who consist of four Pd-based honeycomb monoliths of lean natural gas-air mixtures. Each square honeycomb monolith is $150 \mathrm{~mm}$ wide and $20 \mathrm{~mm}$ long, with square-shaped cells whose sectional area is $1 \mathrm{~mm} \times 1$ $\mathrm{mm}$. In order to control the flow rate of natural gas and air, GMS0050BRSN200000 natural gas meter and CMG400A080100000 air meter with $0-50 \mathrm{~L} / \mathrm{min}$ and $0-80 \mathrm{~m}^{3} / \mathrm{h}$ of full-scale range, which get electric from manostat to operate, were equipped. Each catalytic burner has one natural gas meter, while they share the same air meter.

At the beginning of igniting the burner, the gas reacted in condition of burning. After eight or ten minutes, the blue flame was achieved above the monolith and gradually disappeared when the catalyst started glowing red internally as the temperature inside the monolith increased. And the flow rate of air should be changed for the condition of catalytic combustion.

\section{Result and Discussion}

\subsection{The Variation of Exhaust Gas Constituent}

Near-zero pollutant emissions of catalytic combustion burner. Figure 2 showed how each composition of emission gas changed when the experiment operating. We can grasp the whole variation trend of the content of emission gas. The content of $\mathrm{CO}$ rose at first, and it arrive at the greatest value about eighty minutes, and then the content of $\mathrm{CO}$ gradually decreased, so that natural gas nearly totally reacted. In addition, though the total content of NOx increased continuously, the content is under 5 ppm, which almost can be ignored (Table 1).

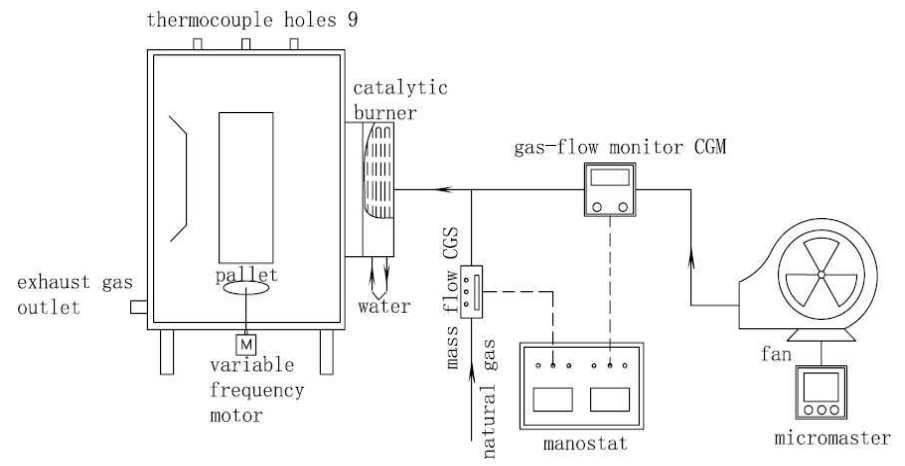

Figure 1. Combustion system of catalytic combustion burner.

Table 1. Composition and content of exhaust gas of catalytic combustion burner.

\begin{tabular}{ccc}
\hline Sample & Compo Sition & Content \\
\hline Natrual gas-air Mixtures & $\mathrm{O}_{2}$ & $19.9 \%[\mathrm{v} / \mathrm{v}]$ \\
\hline Natrual gas & $\mathrm{H}_{2} \mathrm{~S}$ & $1.63 \times 10^{-6}[\mathrm{~mol} / \mathrm{mol}]\left(2.47\left[\mathrm{mg} / \mathrm{m}^{3}\right]\right)$ \\
\hline \multirow{3}{*}{ Exhaust gas } & $\mathrm{O}_{2}$ & $9.65 \% \mathrm{v} / \mathrm{v}$ \\
& $\mathrm{Co}_{2}$ & $6.25 \% \mathrm{v} / \mathrm{v}$ \\
& $\mathrm{No}_{2}$ & $<0.5 \times 10^{-6}[\mathrm{~mol} / \mathrm{mol}]\left(1.03\left[\mathrm{mg} / \mathrm{m}^{3}\right]\right)$ \\
& $\mathrm{Co}^{3}$ & $4.53 \times 10^{-6}[\mathrm{~mol} / \mathrm{mol}]\left(5.66\left[\mathrm{mg} / \mathrm{m}^{3}\right]\right)$ \\
& $\mathrm{Ch}_{4}$ & $0.432 \times 10^{-6}[\mathrm{~mol} / \mathrm{mol}]\left(0.309\left[\mathrm{mg} / \mathrm{m}^{3}\right]\right)$ \\
\hline
\end{tabular}

Source: National Institute of Metrology (NIM). 
Apart from the data we measured, there is also a test report of composition and content of exhaust gas produced in catalytic combustion of natural gas provided by NIM, it can tell us that the contents of $\mathrm{CH}_{4}$ in exhaust gas was less than $5 \mathrm{ppm}$ and the emissions of $\mathrm{NO}_{2}$ and $\mathrm{CO}$ were also closed to zero. According to the result of composition and content of exhaust gas detecting by flue gas analyzer and NIM, we can see there still produced a lot of $\mathrm{CO}_{2}$ when natural gas reacted, However, there are several toxic substance exist. We can put the exhaust gas into greenhouse, so that we can decrease the emission of $\mathrm{CO}_{2}$ as well as provide vegetation with $\mathrm{CO}_{2}$ that's needed during photosynthesis.

\subsection{The Experimental Results}

When filling water, well-distributed water was absorbed by the wall of pottery clay container and not seeped out side. The wall of pottery clay container has not cracked for long time. When filling water again after that there was not a crack in the wall (Figure 3).

\section{Conclusions}

Avoid Natural gas catalytic combustion achieves a real sense of low carbon, denitration emissions, and flue gas at high temperatures to produce sterile components and new Fresh air is the same. Because of its burning stabil-

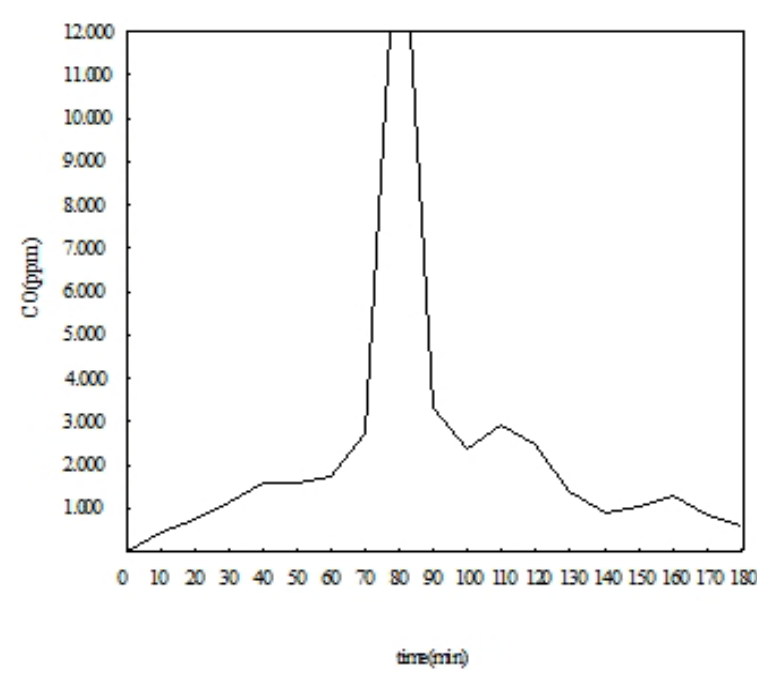

$\infty$

Figure 2. Variation of exhaust gas constituent.

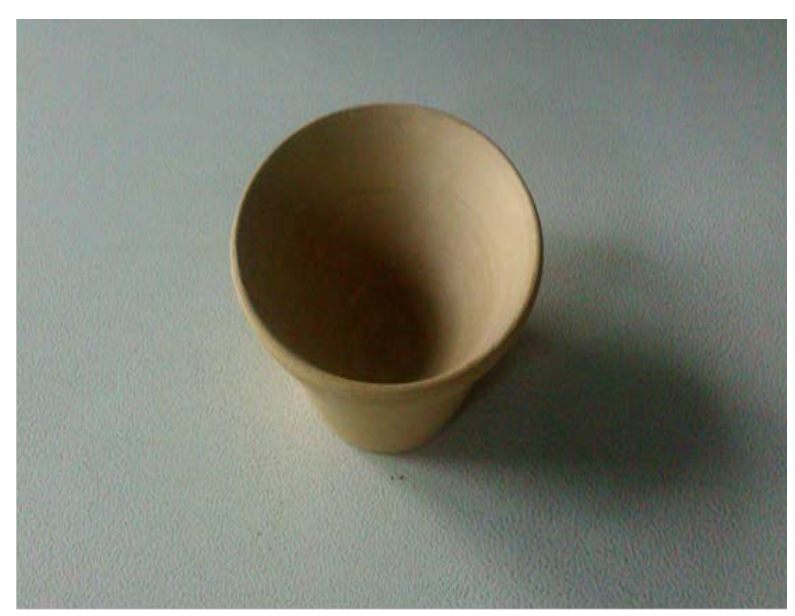

Figure 3. For comparison before and after heating.
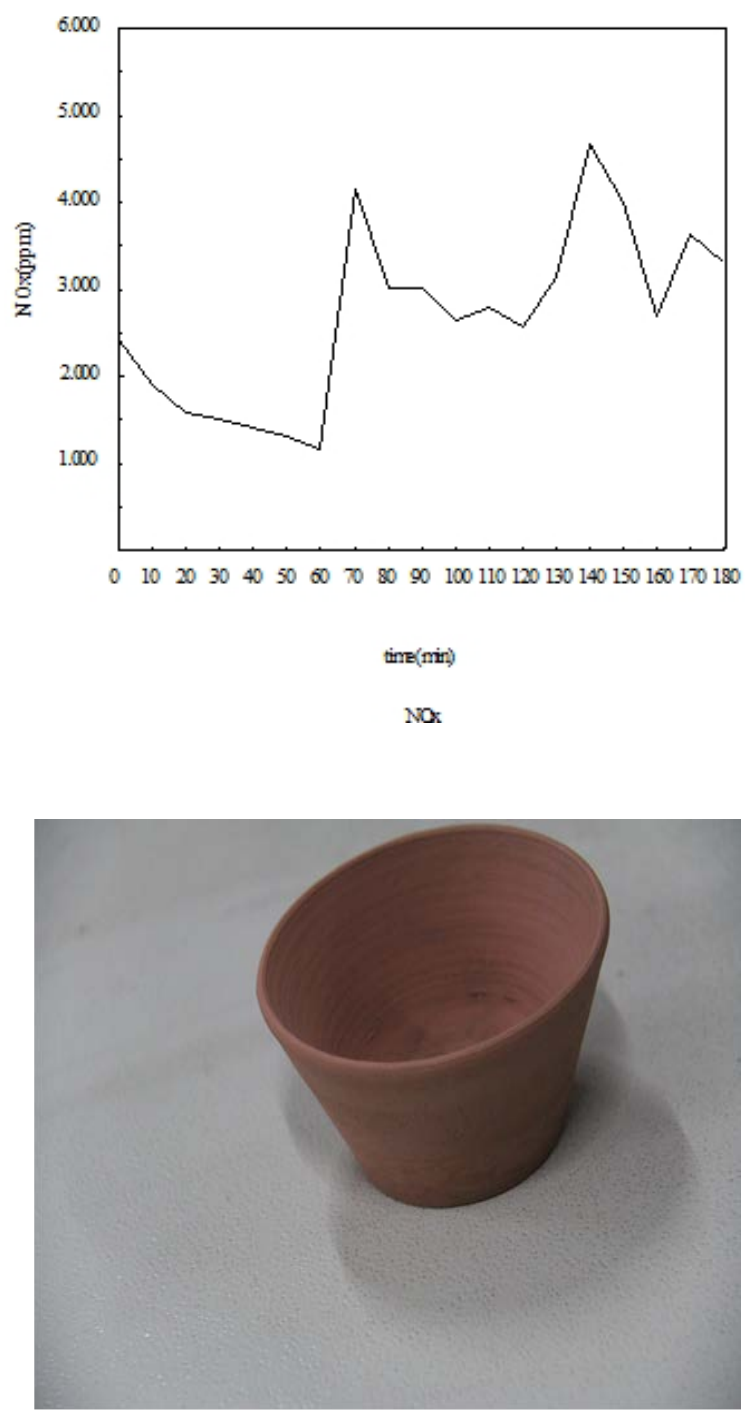
ity of Burns, burns and the near-zero pollutant catalytic combustion of natural gas plays normal burning irreplaceable role in heat supply part, food industry, chemical industry and furnaces, metallurgical industries and agriculture.

Natural gas catalytic combustion-infrared heating technology received wide attention with it high efficiency, low running costs and less pollution and potential applications. Using catalytic combustion stoves can not only reduce production costs, but also can effectively control the pollution of the environment. With ever increasing people's awareness of environmental protection, this form of pollution-free combustion will have wider space.

\section{Acknowledgements}

The project was sponsored by the Beijing Municipality Key Lab. of Heating, Gas Supply, Ventilating and Air Conditioning Engineering; 2014 Funding Project (Building Environment and Facilities Engineering, Water supply and Sewerage engineering), the Core Course of Heat Transfer and Fine Quality Course of Thermodynamics.

\section{References}

[1] Liu, H.W. and Xia, X.L. Analysis on Greenhouse Effect and Control Countermeasures Dalian Environmental Monitoring Center, Dalian Liaoning 116023.

[2] Dai, J.H. and Yan, L. Research Introduction of Greenhouse Effect and Global Warming.

[3] The Effect of Global Greenhouse Effect and How to Deal with Liu Changing Fu Guobin Research Introduction of Geography Chinese Academy of Science.

[4] Zhang, S.H., Dupont, V., Zhou, Q. and Williams, A. (2008) Mechanisms and Applications of Catalytic Combustion of Natural Gas with Near-Zero Pollutant Emission. Science Pres. PR China, ISBN 978-7-03-020647-3.

[5] Greenhouse Effect and Kyoto Agreement Cheng Zhixiang Wxi 214081.

[6] Sidweli, R.W., Zhu, H.Y. and Kee, R.J. (2002) Catalytic Combustion of Premixed Methane-in-Air on a High-Temperature Hexaaluminate Stagnation Surface. Cmnbustion Institute, 29, 1013-1020. http://dx.doi.org/10.1016/S1540-7489(02)80128-6

[7] Zhang, S.H., Lin, H. and Wei. S. (2009) Natural Gas Catalytic Combustion Theory and Application. Chemical Industry and Engineering Progress, 28, 115-117.

[8] Zhang, S.H., Dupont, V., Williams, A. and Rickett, G. (2010) Mechanisms and Applications of Catalytic Combustion of Natural Gas in the Presence of Sulphur Compounds. Science Press. P R China, ISBN 978-7-03-026713-9.

[9] Research on the Thermal Efficiency and Characteristics of Energy-Saving in Catalytic Combustion Burner Lining Beijing University of Civil Engineering and Architecture. 